\title{
SANTERÍA GRAND SLAM: \\ AFRO-CUBAN RELIGIOUS STUDIES AND THE STUDY OF AFRO-CUBAN RELIGION
}

Living Santería: Rituals and Experiences in an Afro-Cuban Religion. Michael Atwood Mason. Washington DC: Smithsonian Institution Press, 2002. ix + 165 pp. (Paper US\$ 16.95)

Divine Utterances: The Performance of Afro-Cuban Santería. KATHERINE J. HAGEDORN. Washington DC: Smithsonian Institution Press, 2001. xvi + 296 pp. (Cloth US\$ 40.00)

The Light Inside: Abakuá Society Arts and Cuban Cultural History. DAVID H. Brown. Washington DC: Smithsonian Institution Press, 2003. xix +286 pp. (Cloth US\$ 44.23)

Santería Enthroned: Art, Ritual, and Innovation in an Afro-Cuban Religion. David H. Brown. Chicago: The University of Chicago Press, 2003. xx + 413 pp. (Paper US\$ 38.00)

Ethnographic objects behave in curious ways. Although they clearly are "our constructions," field sites and even topically circumscribed (rather than spatially delimited) ethnographic problems lead double lives: places and problems change not merely because they factually undergo historical changes, but because researchers come to them from historically no less changeable epistemic vantage points. One can imagine generational cohorts of ethnographers marching across the same geographically or thematically defined terrain and seeing different things - not just because of substantial changes that have factually occurred, but because they have come to ask different questions. The process obviously has its dialectical moments. The figures we inscribe in writing from fleeting observations (based on changing theoretical conceptions) are no less subject to history than the empirical grounds from which 
our discursive efforts call them forth. The result is a curious imbrication of partially autonomous, but also partly overlapping, historicities of lives and texts which, at times, are more difficult to keep apart than it would seem at first glance. At least in the study of Afro-Cuban religious culture, the two practical and discursive fields - one circumscribed by the practical, but perhaps misleading label "Afro-Cuban religion,"1 and the other designated by whatever term one might like to affix to the study of it - cannot be easily separated: much as in the Brazilian case (Braga 1995, Capone 1999, Matory 1999, 2001), practitioners of Afro-Cuban religions and their ethnographers have engaged each other in a dialogue since at least the second decade of the twentieth century. That it took us so long to understand this fact has much to do with the way both "Afro-Cuban religion" and "Afro-Cuban ethnography" originally (and lastingly) became discursively objectified: the former largely under the sign of a search for "authentically African" elements in New World cultural practices, the second as an instrument for "verifying" (and thereby authorizing) such "Africanisms" (Scott 1991).

When the authors of the books under review (as well as myself) began their research on Afro-Cuban religions in the mid to late 1980s, the search for, and authentication of "Africa in the Americas" was still one of the reigning agendas in the anthropology of Caribbean and African American societies (generally not exactly a hotbed of methodological reflexivity or theoretical sophistication at the time). Neither was revolutionary Cuba a particularly well-worked field of research. Though a sizable prerevolutionary literature did exist, ethnographic research on the island was languishing after an initial burst of important publications in the 1960s, and foreign (especially U.S.based) researchers had not been granted research visas for projects concerning popular religious culture since (and perhaps because) Oscar Lewis and his group had been asked to leave the island in 1970. Thus while the Cuban Editorial Ciencias Sociales mainly kept republishing Fernando Ortiz's oeuvre throughout the so-called period of scientific atheism, until the end of the 1980s, virtually all the genuinely fieldwork-based Anglophone monographs on the subject dealt with Afro-Cuban religious practices among Cuban exiles - in New York and New Jersey ${ }^{2}$ or Miami. ${ }^{3}$ In other words, all of us began

1. It might be well worth asking what exactly is "Afro," "Cuban," or "religious" about forms of knowledge and practice that, since the second half of the nineteenth century, have been claimed as "theirs" not just by descendants of African slaves, but also by socially white Cubans; that have nowadays spread across the Western Hemisphere as well as Europe; and for which the label "religion" (even though it is used by practitioners themselves) may provide a rather limiting analytical gloss.

2. As with the dissertations by Murphy 1980, Friedman 1982, Brandon 1983, Gregory 1986, and Brown 1989.

3. As in the case of Castellanos 1976 and Palmié 1991. 
our fieldwork in Cuba at a very specific historical conjuncture: the point at which Cuba's economic and political relations with the Soviet Union soured, and the latter's falling apart in 1991, not only plunged the island into the unexpected and unprecedented crisis of the periodo especial, but fundamentally changed the rules of ethnographic engagement there. If, during the 1970s, ethnographic work on governmentally unsanctioned topics was made nearly impossible by the laws regulating Cuban citizens' contacts with foreigners (to a point where unauthorized conversations with foreigners could be interpreted as a potentially "precriminal" act of ideological diversionism), by the early 1990s, not only could ethnographers submerge themselves in the waves of foreign tourists streaming to Cuba in ever larger numbers, but the Cuban state's own recognition that the nation's African heritage represented a "country factor advantage" worked in our favor as well (to a point where, by now, publications by foreigners have completely overtaken the native Cuban output).

By then, of course, what we were seeing in Cuba had not only changed since Melville Herskovits sent his student William Bascom to Cuba to gauge the strength of local "African retentions" and relative superficiality of Catholic "syncretism" (Bascom 1950, 1951, 1953). We were also looking at it through very different spectacles largely because we had developed our perspectives on our subject in accordance with the "reflexive" and "historical" turns in the social sciences (as the glib phrases go). We had also read Sidney Mintz and Richard Price's influential 1976 essay (Mintz \& Price 1992) that urged a rigorous historicization of the processes out of which contemporary African American cultures had emerged. And we had become skeptical of the dubious methodological moves by which decontextualized data from both sides of the Atlantic tended to be short-circuited in order to derive African origins for contemporary New World cultural forms. Finally, in our North American fieldwork we had become dissatisfied with the neofunctionalist interpretations that reduced Santería to a surrogate mental health care system (e.g., Sandoval 1979) resorted to by immigrants riddled with acculturationinduced psychological problems,${ }^{4}$ and we had plainly gotten bored with the descriptive lists of deities and their attributes ("Chango's color is red, his sacrificial animal is the ram, owns the drums, manifests himself in thunder and lightning," and so forth) characteristic of much of the recent literature at the time. ${ }^{5}$

4. It became clear to me that this was not so - or, at least not predominantly - soon after I stepped off the plane in Miami in the spring of 1985. Not only was Miami, by then, dominated by Cubans, both economically and culturally, but, as one of my informants, a cowrie shell diviner, put it to me later that year, "none of my clients are any crazier than you and me." I still think he was right.

5. This genre is, of course, far from dead; see Barnet 2001:44-69. 
Also, but not of less importance, however, was the fact that all three authors under review here were then in the process of becoming practitioners of Afro-Cuban religion themselves. Following in the footsteps of French scholars of Brazil (such as Roger Bastide or Pierre Verger), but going against much of traditional Anglophone academic praxis, ${ }^{6}$ Mason, Hagedorn, and Brown all underwent initiation into regla de ocha (better known as Santería), and therefore write about religious forms and traditions that they do not regard merely as ethnographic givens "out there," but which, to varying degrees, and certainly with different rhetorical emphasis, these authors claim as parts of their own lives and biographies. If, as I have argued elsewhere (Palmié 1995, 2001), santeros have been writing in rebuttal of academic treatments of their religion for quite some time, the line between "them" and "us" has now become blurred: the dialogues of the future, it would seem, may well be conducted between santeros who have turned themselves into scholars of their religion, and scholars who have turned themselves into practitioners thereof, with an occasional secular student of such matters (such as myself) chiming in from the margins.

Starting at the most self-conscious end, Michael Mason's Living Santería reads, in part, like a road map into regla de ocha. In four brief chapters, Mason tracks what he calls "experiences that are common to most practitioners as they enter the tradition" (p. 11). His goal is to elucidate "the lived experience of various human subjects at different levels of involvement" in regla de ocha (p. 11), and the transformation their "subjectivity" undergoes as their relationships and interaction with other practitioners, spirits, and divine entities develop and intensify. Framed by an introduction, a more analytical fifth chapter, and a conclusion, the course runs from an initial divinatory consultation undertaken by a female client for essentially secular reasons, through the rites of bestowal of the guerreros (the warrior deities Eleguá, Ochosi, and Ogún) and its attendant establishment of moral relationships with a human initiator and a set of deities, on to a chapter about the vicissitudes of managing religious and secular projections of identity among practicing santeros as they traverse North American social terrain, and culminates in a step-by-step description of the initiatory process itself. What Mason is after, it appears, is the gradual socialization into, and individual habituation of, conditions of agency and experience opened up by, defined by, and validated through what, in effect, constitutes a process of religious conversion. That is largely what

6. Recall the famous ending of Evans-Pritchard's Nuer Religion (1956:322): "Though prayer and sacrifice are exterior actions, Nuer religion is ultimately an interior state. This state is externalized in rites which we can observe, but their meaning depends finally on an awareness of God and that men are dependent on him and must be resigned to his will. At this point the theologian takes over from the anthropologist." 
he is talking about, or so it seems to me, when he posits transformations of "subjectivity" through increasingly embodied knowledge that generates new feelings of both control and submission, as well as new arenas for engagement of similarly structured "subjectivities," both human and divine. ${ }^{7}$ If so, however, it is not clear why Mason cuts himself off from the increasingly sophisticated literature on conversion, ${ }^{8}$ which has long left behind the lingering Weberian teleological emphasis on properly rationalized world religions, and might have opened up perspectives that Mason's narrowly phenomenological approach cannot address. What Mason tells us is that the gradual process of becoming a santero or santera does something for one's sense of self as a moral (and cosmological) agent. But were it not for the ideology of a necessary sudden conversion experience - where Saul falls from his horse, and stands up as Paul to thank his savior - the same could be said about evangelical Protestantism. Few people convert to even such zealous gods as Yahwe all at once, and Mason's account of being "hailed by the oricha," and gradually learning to answer their call (and, one imagines, learning to want to answer it, too) might have been a useful addition to a literature that aims at removing what Robin Horton (1984) once called the "Judeo-Christian spectacles" still riding on the noses of far too many sociologists of religion.

As it stands, however, Living Santeria does not fully live up to the "interstitial" qualities that Mason sees as constitutive of all ethnographic endeavors (not that there are too many people around, these days, who think of ethnography as productive of morally unencumbered, purely objective knowledge!). Nor does its episodic structure, focusing on representative events in the life of santeros in a state of becoming, deliver the kind of sociological and historical depth that would allow other scholars to fruitfully generalize from it. Mason is at his most effective when he deliberately dons both hats at once, and speaks about how for him, for example, dreaming of the deities he worships - and studies - comes to inform a unified vision of an epistemic project in which anthropological knowledge affects his religious quest, and divinely revealed truths must, for the practitioner-scholar, inform any auto-ethno-

7. Consider the following passage (p. 114): "Ritual is thought to change situations in the 'real world,' and as an initiatory religion, the Regla de Ocha transforms human subjectivity by placing it into increasingly intimate relations with the subjectivity of the supernaturals. Through the instrumentality of ritual, practitioners evoke different social positions that culturally imply differing capacities, competencies, and authority. Participating as the intended beneficiary of a ritual transforms an individual's subjectivity in important ways, at the same time that performing a ritual reinforces a priestess's subjectivity and her role as an "instrument of the orichas."

8. For example, Comaroff \& Comaroff $(1991,1997)$, Hefner $(1993,1998)$, Keane (1997), Landau (1999), Meyer (1999), Peel (1990, 2000), Price (1990), Rafael (1988), or the contributions to Van der Veer (1996) to mention just a few. 
graphic endeavor. Having clarified the conditions of possibility for such a hybrid epistemological stance (if only for himself) is a contribution in itself. ${ }^{9}$ Despite their lack of educational credentials comparable to ours, the intellectual virtuosi (to use a Weberian term) among Mason's santero peers have done no less for at least the past century - poring over our textual productions, and engaging us in debate, they have been rationalizing our modes of knowledge production just as much as we have rationalized theirs.

This much quickly becomes evident in the second book under consideration, ethnomusicologist Katherine Hagedorn's Divine Utterances, a work that also aims to straddle the insider-outsider gap in the literature on AfroCuban religion. Much like Mason, Hagedorn tells her readers straight away that "it has been through the lens of folkloric performances that I have framed lo religioso, the religious, and now it is through religious performance that I frame lo folklórico, the folkloric" (p. 6). ${ }^{10}$ She, too, steers her readers toward understanding her book as a sort of conversion narrative in which her spiritual persona as a future daughter of the deity Ochún repeatedly generates mythologically prefigured experiences of dramatic conflict with her divine guardian's sexual antagonist, Ogún. Yet Divine Utterances has a very different agenda from Mason's Living Santería. For while Mason aims to close the distance between life and text, foregrounding "lived experience" at the expense of analytical depth, Hagedorn seems far more comfortable with maintaining or even generating an ironic tension between them. In fact, she is arguably at her best when she foregrounds the paradoxical and contradictory, for example, when she monitors the deliberate, but hardly successful attempts on the part of Cuban cultural engineers (both before and during the Revolution) to incorporate Afro-Cuban cultural forms into - changing - national projects by eviscerating them of their religious content. Likewise, Hagedorn is astute and incisive when she confronts the institutional history of the project of creating a "National Folklore" in step with revolutionary consciousness with the deeply conflicted memories of state agents whose well-meaning and deeply felt need to insure "authenticity" resulted in the growth of religiously defined networks of power and patronage within the Conjunto Folklorico Nacional - an ostensibly secular instrument of revolutionary cultural production; or when she exposes the covert racism at the heart of a supposedly emancipatory project (namely, to liberate the cultural expressions of black workers from prerevolutionary bourgeois denigration) that nevertheless harked back to a

9. For a highly idiosyncratic (to say the least), but methodologically more consequent precursor to such epistemological hybridization, see Meyer and Bede-Fagbamila's jointly authored "Divination of Ethnography" (1991).

10. Happy are the Hispanophones, who can coin such indeterminate nominalizations without having to speak of religions and folklores! 
conception of both Africanity and religion as impediments to social progress and modernization. ${ }^{11}$

Such contextualization lends an ironic distance to Hagedorn's more personal reflections, such as those on her apprenticeship as a female batá drummer (an oxymoronic concept) to Alberto Villareal, one of the Conjunto's current leading performers and practicing olú añás (consecrated drummer). But it never results in an authorial stance that betrays anything less than her commitment to the eminently masculine musical tradition she is trying to formally master, and the religious precepts that underlie it. Her stance becomes even more evident in what is (at least in my idea) the most fascinating chapter of her book, aptly entitled "Blurring the Boundaries: Merging Sacred and Profane." What happens, conceptually, Hagedorn asks here, when a secularly conceived folkloric performance of programmatically modified sacred rhythms and chants in front of an audience composed of tourists, secular aficionados, hustlers, and practicing santeros does not merely involve choreographed simulacra of possession behavior on stage, but accidentally triggers a divine possession among the audience? And how would we know the difference? Is a rhythmic performance conceived of as sacred audibly any different from the same set of drumbeats intended as a profane utterance? Hagedorn's answer is yes - and no: "precisely because the performances sound the same," (p. 111) she writes about the depiction of divine possession in Gloria Rolando's 1992 film, Oggún,

\begin{abstract}
because the space between the sacred and the secular is inaudible, understanding the terms of where and how the sound gets produced might be more important than what is heard. The intent of the possession performance gains primacy over the performance itself, but because of a shared corpus of body memories of possession, some aspect of the sacred is recalled. Clearly, in the case of the feigned possession, the intent is not to bring down the deity - that is, the intent is not to get possessed, but rather to mimic possession so expertly that the experience seems real on film. But the success of the staged possession performance relies almost completely on those bodies who have been possessed, so the boundaries between "source" and "derivation" become blurred or even irrelevant.
\end{abstract}

Quite clearly, Hagedorn puts her finger on a core contradiction at the heart of the anatomía del proceso folklorico (part of the title of Hagedorn's origi-

11. In no small part, the dilemma inherent in the revolutionary Cuban project of creating a "National Folklore" was that it supposed a collaboration between scholars an practitioners of religions whose existence as religions was to be extinguished by the force of a future socialist epiphany. As David Brown tersely summarizes Hagedorn's account, it is probably also true that "at least some of the intellectuals [involved], consciously or unconsciously believed that you could take the informant out of the mala vida cubana [Cuban low-life, a term popularized by Fernando Ortiz], but you could not take the mala vida cubana out of the informant" (The Light Inside, p. 206). 
nal dissertation): neither we, nor the designers of the folkloric spectacles that "real santeros" produce under the auspices of a "real existing socialism" can really know. To what extent the sacred is prone to intrude into secular performance (or vice versa: to what extent such performances act upon the liturgical context within which their choreography works) is a contextual issue and one that cannot be blanketed by statements about the phenomenology of "lived experience" (for isn't faking possession, even in a sacred context, a "lived experience," too?). This is precisely because there simply is no empirical difference between the two kinds of realities, sacred and secular. For all practical purposes, they look and sound the same. Who could tell what really is in the body of someone enacting the part of a divine persona? Is it someone wanting to show off his or her skills at performing the gestural repertoire of divine histrionics for a variety of personal motives? Is it a state-employed santero trained to perform "as if," and drawing a line between different values produced through gainful employment and sacred "work"? Or is it a genuine divine presence with its own "wholly other" reasoning and rhyme?

At moments such as these, Hagedorn makes a powerful and really rather understated contribution to a much larger set of issues and conversations (e.g., Boddy 1994, Das 1998). Rather than pursue such lines of inquiry beyond one truly dazzling chapter, however, she goes onto other subjects, chronicling the problems of life in Cuba during the special period and presenting descriptive data on ritual music and its ambiguous "folkloric" transformations (nicely accompanied by a CD), a somewhat disjointed account of the criminalization of Afro-Cuban religion, some rather impressionistic remarks on contemporary Cuban forms of racism and their articulation with the exploding tourist industry, and further explorations of her own relationships to the deities she studies and serves. Yet despite its disorganized character, Hagedorn's book does represent a critical achievement, precisely because she manages to successfully call into question the boundaries between the supposedly "authentic" and its "fabricated" doubles, exposing the difficulties of delimiting "real experiences" from their supposed "empirical symptoms" (which are visually and audibly indistinguishable from good fakes) and illuminating the range of contradictions the Cuban state courted in half-heartedly embracing its nation's popular traditions.

If Hagedorn is at her most incisive when she switches from a romantic rhetorical mode to an ironic one, David Brown's The Light Inside can likewise be read as a brilliant, tongue-in-cheek epistemological meditation on method (and its madness) in Afro-Cuban, and Afro-Atlantic studies more generally - and it is instructive to consult it first before going on to read his long-awaited magnum opus, Santería Enthroned. On the surface, The Light Inside is a book about a single set of unusual looking objects assembled on, or next to, a table covered with a black velvet drape brightly embroidered with silk: plumed staffs, small cylindrical or goblet-shaped drums, a cru- 
cifix, something that looks like a monstrance, and a red suit with a conical headpiece. Yet like all other things that humans tinker with or produce, this curious assemblage has not just a material, but also a discursive presence. As Brown argues in taking cues from Appadurai (1986) and Kopytoff (1986), the objects in question look back on a complicated social life and biography, one that is constituted through the accumulation of narratives around them: how they came to be assembled in the way Brown was able to photograph in 1992, what highly differentiated meanings they hold for their makers and users, and how these and similar "sacra" pertaining to the secret brotherhood, abakuá, became the referents of a polyphonous swirl of public representations that have come to envelop them since the middle of the nineteenth century - all that is a matter that not only defies typologizing maneuvers ("this is an example of an abakuá altar"), but asks for what Brown calls a historical "contextualization of the archive" (p. 241) that nowadays enables the beholders of these objects to place them under coherent descriptions, be they of sacred or secular nature.

As Brown himself repeatedly acknowledges, his is ultimately just another such narrative. Yet precisely because he eschews a rhetorical stance outside the stream of discourses washing over the objects on the altar of the abakuá lodge he chose to call Eforí Eñongo, Brown manages to first tell the story of these objects in a manner that largely coincides with the views of both contemporary Cuban obonecues (members of abakuá) and their scholarly analysts, and then to read that story itself as a historically dense palimpsest of past accretions: an "archive," the structure of which can be deciphered by careful historical contextualization. Accordingly, Brown initially situates the deeply personal meanings the altar objects of Eforí Eñongo hold for the man he calls Jesús Nasako (who renovated them in 1979) within larger narratives internal to the association itself that concern abakuá's mythical origins and historical career. At the same time, however, he shows that at another level, parts of such stories also became canonical within very different discursive traditions: those produced by the Cuban state and its legal apparatus in its colonial, republican, and revolutionary incarnations; others generated by a variety of observers (ranging from police inspectors to artists and local color writers, as well as ethnographers and art historians); and yet others originating with anthropologists and historians, for whom the "case" of Cuban abakuá appears to speak to a range of issues pertaining to the cultural history of the African diaspora.

The results of Brown's exegesis of these partly autonomous, but mutually articulated discourses should give us all pause. Take, for example, his characterization of the scholarly end of things: for too long, Brown argues, we have represented "art makers, objects, and ritual actions" as " transparent' to a set of timeless cultural values or "core principles,", supposedly characteristic of ethnographically delimitable groups in Africa and the New World (p. 4). Once such "transparency" has become discursively established, it is a short 
step to representing African American objects "as the essential descendants of their African source cultures" by imaginatively stripping away incongruent "additions" so as to render them "traceable, like isotopes, to a set of African morphological prototypes within a relatively uniform and transatlantic semantic field" (p. 5). Yet for Brown, even approaches based on models of interchange between heterogeneous cultural systems, and often associated with terms such as "syncretism" or "creolization," ultimately generate stories whose analytical "signifying potential" ought to be confronted with the remarkable account of Brown's key informant Jesús Nasako. "No one besides me would be able to explain to you the meaning of these things," the man told Brown (p. 5), "because they come from my personal experience and family history" - and, one would like to add, the history of Cuba itself. Never mind that when he renovated Eforí Eñongo's titleholders' sacred staffs of office, Jesús Nasako did work according to a template that arguably has African origins, and that is seen as originating in Africa by contemporary obonecues and scholars alike: the fact that the staff of the incumbent to the Abasonga title bears a mass-produced brass medal depicting St. Christopher may be taken as evidence of a syncretistic process that analogizes the transitional role of the sainted ferryman in Catholicism with that of Abasonga, who, as a figure in abakuá's founding myth, is instrumental in transacting the mystery from one side of an African river of the Cuban imagination to the other. Jesús Nasakó affixing this medal to Abasonga's staff, however, has nothing to do with what Herskovits (1937) called a mechanically evolving "confusion of theological concept," but rather with the fact that Jesús Nasako received it as a gift from his baptismal godfather in 1958. The decision was entirely deliberate, and although informed by a specific "ethnoaesthetic" (as Brown might call it), ultimately cannot be reduced to it. The same holds for his 1979 decision to crown Mokongo's staff with a chromed nude female figure with outstretched arms. Again, and for aesthetic, theological, and biographical reasons very much his own, Jesús Nasakó saw a semblance of Sikan (the female mythological character who originally discovered the secret and was put to death for it) in a hood ornament of a Ford Edsel, which he stole well before the Cuban Revolution put an end to the importation of American cars, and eventually inserted into a very different regime of value, thus Africanizing and sacralizing a North American commodity fetish (The Light Inside, pp. 84-93). ${ }^{12}$ Who, indeed, but Jesús Nasako, could have told that story? And what an allegory of transatlantic knowledge production it is!

12. Knowing him myself, I wouldn't find it surprising if Jesús Nasakó initially incorporated it in the virtual warehouse of components of future "sacra" that he, a handyman if there ever was one, and a highly self-conscious one at that, keeps in a shed by his house in El Cerro. 
But of course, ritual art makers such as Jesús Nasako never operated in a vacuum. Hence the story of how their productions graduated (in Brown's terms) from public indexes of African atavism or criminal evidence to folkloric specimens and expressions of Cuba's national cultural heritage is one that, Brown rightly insists, cannot be told separately from the story of the growth of African derived traditions in Cuba, or even apart from Jesús Nasako's own biography as a maker of objects over which semantic and political contests have raged for well over a century now. And just as Brown's fieldwork allows him to pinpoint inconsistencies in the stories that members of abakuá tell each other (and their ethnographers), for example, about the historical transmission of the sese drum's shape and secrets (The Light Inside, pp. 98-111), so does his reading of the "archive" unearth a welter of contradictions. For Brown, "comparative ethnography and art history engage not simply in the contrast and comparison of practices, but in the contrast and comparison of representations of practices" (The Light Inside, p. 133, emphasis in the original). Hence the task he sets himself in the second part of The Light Inside is not to ask "whether Abakuá society objects are or are not 'art and philosophy.",13 What Brown wants to know is "what historically situated truth claims were made about and around [such] objects in order to constitute their particular status at a given moment [and] how individuals, groups, and institutions have appropriated things Abakuá ... in order to make cultural meaning and further local, national, and international agendas" (The Light Inside, p. 133).

This he proceeds to show in such stunning detail that a single example of his treatment of abakuá masking traditions and their iconography must suffice to render the flavor of his interpretations. Brown's discussion of the long-term Cuban resident Basque artist Victor Patricio Landaluze's depictions (published in 1881) of íreme (spirit-embodying dancers wearing a complexly patterned cloth body mask) thus makes no bones about the African derivation of the "saco de íreme." On one level of interpretation, Landaluze might well be said to have provided a visual record of a body mask of the Cross River type in Cuba more than thirty years before P. Amaury Talbot published a photograph of its "supposed" ancestor in southeastern Nigeria. But this is precisely the kind of reasoning Brown wants to circumvent and complicate, for the transformation of Landaluze's imagery into an icon of changing public meanings attached to abakuá (from menace to Cuban civilizational progress to valued African heritage, from symptom of criminal atavism to evidence of "African art and philosophy" in the Americas) took off from what was already, in almost every way, a deeply hybridized image. As a trained art historian, Brown has no trouble reading Landaluze's work as a visual transposition of European postural principles (ranging from classi-

13. An ironic echo of the subtitle of a book by Brown's mentor Robert Farris Thompson, Flash of the Spirit (1983). 
cally Greek to Renaissance and Baroque themes) onto an Afro-Cuban subject matter (The Light Inside, pp. 133-44). What is "African" or "European" in the resulting image is hard to tell, and indeed perhaps beside the point. For given that Landaluze's "El Náñigo" lithograph is nowadays held to represent an original stage of "African" authenticity in Cuba, not just by scholars but by members of abakuá as well, would we even want to speak of syncretism here? And who would be its agent?

For Brown, it seems, the question itself is misguided. Rather than proceeding from postulated cultural source entities that supposedly come in contact with each other, and then generate mixtures, syncretisms, or more general states of hybridity and epistemic murk (as Homi Bhabha or Michael Taussig might put the matter in their own, more flamboyant ways), Brown sees his task as tracking the movements of single objects between and across fields of signification (whoever's culture they may be thought to constitute). And this is precisely his agenda in Santería Enthroned, ${ }^{14}$ a magnificent and truly interdisciplinary book, in fact, perhaps several books in one. Santería Enthroned can be read as the first genuine social history, worthy of the name, of Afro-Cuban religion in the nineteenth and twentieth centuries, a superb ethnography of forms of historical consciousness based on more than a decade of intermittent fieldwork in Cuba, a richly illustrated art-historical monograph, an eloquent testimony to the complexity of Caribbean cultures, and a searing challenge to methodology and theory in Afro-Atlantic studies. Organized around a central multivocal image of divine royalty, Santería Enthroned delineates a good century of changes in institutional structure, ritual practice, and iconographic form, carrying the reader through a series of minutely detailed episodes crucial to the formation of what we, today, know as regla de ocha.

In the process, Brown sweeps away a whole range of time-hallowed conceptions about the kind of organic processes that supposedly led to the implantation of originally African cultural forms in New World settings, and their gradual erosion (or, alternatively, retention) among the descendants of enslaved "bearers" of such African cultural forms. What emerges instead is nothing short of a radical revision of Afro-Cuban cultural history; for Brown, regla de ocha does not represent a diasporic specimen or variant of "Yoruba religion" (something that cannot be said to have existed in Africa even as late as the nineteenth century) that was imported whole-cloth by the thousands of enslaved Yoruba-speakers who reached Cuba in the first half of the nineteenth century. Rather, regla de ocha (and specifically the cult of Ifá) was literally cooked up, no earlier than in the last two decades of the nineteenth

14. The book is partly based on Brown's 1989 dissertation which even then was treated as a genuine contribution to theory in African American cultural history (e.g., Mintz \& Price 1992:x), but to everyone's dismay remained under lock and key in the Yale library. 
century, by fewer than a dozen Africans and their creole descendants living in or near the third barrio of the town of Regla, and it continued to undergo dramatic and contentious transformations throughout the first half of the twentieth century as it spread through western Cuba's provinces of Havana and Matanzas. What is more, while many of the founding figures are remembered today as reformers or rectifiers of traditions that had been incompletely transmitted, or become corrupted over time, when systematically correlated, such contemporary discourses, in fact, reveal exactly the opposite: most of the ancestral figures recalled in invocatory prayers (moyuba) today were crafty innovators who, in selectively drawing on heterogeneous cultural sources (some of which undoubtedly were of Yoruba provenance), did not just systematize and theologically rationalize a "religion" that had not existed as such before (whether in Africa or Cuba). Rather, they also strategically situated themselves in positions of authority and control over the dissemination of the knowledge and practices they had helped to institutionalize.

However, as Brown makes clear right from the start, reducing the case to a simple matter of the "invention of tradition" would equally miss the point: "though I may use the term 'innovation' in generally describing the accomplishments of particular historical actors," he writes in one of the few passages in the book where he seems to speak as both scholar and practitioner, 'I apply the term 'reform' in specific cases to practitioners' historical consciousness and their modes of explanation," for in their view, "baseless and unauthorized changes disrespect the priestly deceased, the egun, who delivered tradition, upon whose shoulders we stand, and to whom we must answer" (Santería Enthroned, p. 11). And it is in following practitioners' own narrative constructions that Brown supersedes the sterile objectivism of the "invention of tradition" conceit. Obviously, discourses about origins and traditions, continuity or discontinuity, authenticity and illegitimacy inevitably express political positions and maneuver. However, the historical vision of contemporary practitioners acknowledges no less, revolving as it does around two ambivalently juxtaposed, and strategically activated, narrative constructions. As Brown puts it, one is

a story of linear continuity with an authentic origin or primordial spiritual
ground: the tierra (homeland) of the Yoruba of West Africa or an ances-
tral personage (egun), for example, or a Lucumí or creole who founded
a rama (branch) of the Lucumí religion in Cuba. The other is a story
about agency, struggle, discontinuity and heroic achievement. (Santería
Enthroned, p. 77)

As far as the second storyline is concerned, Brown's oral historical research leaves no doubt that right from the beginning, struggles over the authorization of what could count as traditional were part of the very process out of which the tradition itself grew - and are remembered as such to this day. Perhaps as 
early as the last decades of the nineteenth century, but certainly by the second decade of the twentieth, now famous priestly figures were forced to undergo reconsecration rituals in order to accommodate rival initiatory traditions that had begun to coalesce locally in Matanzas and Havana. By the mid-twentieth century, the emergence of a new priestly commission, that of the obá oriaté, had not only led to the emergence of what Brown calls two partly overlapping "ritual fields" (one centered on the orichas and another on the oracular deity Ifá/Orúnmila), but split practitioners along the lines of groups dominated by babalawos and others rejecting their claims to ultimate ritual and theological authority. At the same time, by the 1950s babalawos themselves began to engage in fierce struggles over the authority to control the crucial reproductive resource of the Olofin - a sacrum indispensable to the initiation of new babalawos, and therefore a key to the strategic building of hierarchical religious descent-lines (ramas) under the control of single senior priests.

Since Brown's research into the initiatory genealogies of Cuba's babalawos represents one of his most important contributions to a historical anthropology of Afro-Cuban religion, it is worth briefly expanding on the strange career of the Olofin. What Brown's findings indicate is that virtually all babalawos active in Cuba today trace their initiatory descent to five African fundamentos (founding figures) ${ }^{15}$ active in the town of Regla in the last quarter of the nineteenth century. Now according to the narrative tradition emphasizing continuity over disjunctures, some African-born babalawos carried their Olofin secrets to Cuba in the holds of slave ships (a topos repeated in stories about how enslaved babalawos tied their divining chains around their waists, or swallowed the consecrated palm nuts used in Ifá divination before embarking on the Middle Passage). In contradistinction, what Brown calls the "discontinuity/transformation cycle of diasporic narratives" posits the deliberate return of some babalawos to Africa and details their epic quest for this holy grail of Cuban babalawos (which, to my knowledge, lacks documentation in Africa so far), in order to create the conditions of possibility for the reproduction of the cult of Ifá in Cuba. ${ }^{16}$ Yet however the Cuban Olofin tradition may have originated, its initial pace of dissemination was slow and linked to a mechanism of inheritance (by either biological offspring or ritual descendants of the original owner). By the first two decades of the twentieth century, a first and second generation of creole babalawos inaugu-

15. In contemporary parlance, the term fundamento can refer both to a human "founder" and to a ritual object that is "foundational" to religious practice.

16. Note here the ironic congruence of these two narratives with the ways in which twentieth-century scholars have modeled the cultural history of the African diaspora, for while the "former narrative coincides with the Herskovits diffusion school ...; the latter narrative resonates with the Mintz and Price school ... and the recent Black Atlantic work of Paul Gilroy" (Santería Enthroned, 80). 
rated a pattern whereby strategic lending out of Olofin objects by the heads of emerging religious lineages (ramas) to junior babalawos aspiring to build up groups of religious dependents on their own became a political tool for senior Olofistas to control the members of their ritual descent groups. But it also quickened the pace of initiations. By the 1950s, however, the enterprising and (according to Brown's sources) ruthless third-generation babalawo, Miguel Febles y Padrón (1910-86), was to introduce dramatic changes into the pattern. Although new Olofíns had been "born" (as babalawos would put it) in Cuba before, Febles now began to mass manufacture and sell these objects. He also threatened and intimidated rivals who would dare to impugn the authenticity of his Olofin objects, or try to impede his monopolistic project of turning himself into the founding figure for literally hundreds if not thousands of babalawos active, by then, not only in Cuba, but in exile in the United States, Venezuela, Panama, and Mexico.

As a result, "the operative location of Olofin's 'authentic origin' shifted over time," as Brown sums up the bearing of these "stories" on any conception of Afro-Cuban religious history:

\begin{abstract}
In the beginning, as it were, Africans in Cuba saw Olofin's ultimate source as "West Africa," from which nineteenth century babalawos had embarked, and to which their agents are believed to have returned to reclaim Olofin's secrets. Then a small Havana collective of Lucumí founders and later, a short roster of early creoles, became the proximate or local "origin" of this jealously guarded fundamento ... After the 1950s, the "origin" of Olofin, for all intents and purposes, became sited in the fundamento of Miguel Febles. (Santería Enthroned, p. 90)
\end{abstract}

Yet this transatlantically shifting pattern of allocations of "origin" did not end here. For in 1975, in a move deliberately designed to thwart Febles's project of installing himself as the future fons et origo of Ifá in the New World, a group of disgruntled Miami babalawos headed by José Miguel Gómez Barberas flew to Nigeria, acquired what was represented to them as the equivalent of the Olofin, and later invited their Nigerian benefactor Ifá Yemí Eleguibon to officiate over the now autonomous initiation of new babalawos in Miami. Clearly, and much as in the case of the North American black Yoruba Reversionist Movement, ${ }^{17}$ the shrewd maneuver by Gómez and his group to re-activate "Africa" as a viable chronotope of primordial authenticity and legitimacy constituted a major break with tradition, both in the sense

17. This movement emerged in the 1960s (after its founder had been initiated into regla de ocha in Cuba in 1958) and, around the same time, began to resort to similar strategies of turning southwestern Nigeria into a "source" they could tap into to sever the lines of ritual authority and deference that still bound them to their Cuban "elders" (Santería Enthroned, pp. 276-86; see also Palmié 1995). 
of established practice, and with regard to the way that practitioners imagine a seamless flow of knowledge and practices through the conduit of the genealogical construct of the ramas of initiatory descent. However, as Brown is able to show, they did not, and perhaps could not, dispense with elements of the trope of linear continuity: constructing an arguably postmodern, but nonetheless highly traditional transatlantic spiritual genealogy, Gomez claimed that his Nigerian benefactor Yemí Eleguibon was the grandson of one of the four enslaved Africans who, in his view, installed the cult of Ifá in Cuba in the first place! Thus closing a circle of the diasporic imagination, these Miami babalawos not only emancipated themselves from their Cuban sources, but - in conflating suburban South Florida with a "Yorubaland" which they had been reading about since at least the 1930 s - generated a continuity narrative harking back to those very enslaved African fundamentos in Cuba whose legitimatory capacity, to this day, cannot be called into question.

As this example shows, all representations of the past and becoming in contemporary Afro-Cuban religion are highly overdetermined composites - "marvelous hybrids" (Santería Enthroned, p. 288), to use Brown's phrase - whose internal tensions and productive potential are ill-captured by our attempts to sort out its constituent elements according to criteria which ultimately fail to do justice to the historicity of even our own constructions of Africa and Europe (e.g., Mudimbe 1988, Appiah 1992)! This, arguably, is the gist of the second half of Brown's book which he devotes to a painstaking analysis of the ritual iconography of contemporary regla de ocha. For the ideal of divine radiance that contemporary practitioners aim to achieve in the assemblages composing the thrones on which recent initiates display the splendor of the "palace of the obá Lucumí" is no less than such a marvelous hybrid - the result of long and complicated histories of strategic (or even just opportunistic) appropriation of heterogeneous symbols of prestige and grandeur into an ethno-esthetic that cannot be said to have preceded such processes of hybridization, but emerged from them, and presents their momentarily visible result. How else to reconcile a contemporary New Jersey thronemaker's predilection for the style of Louis XV ("in fact, all the Luises") with the fact that what he is creating is an iconic landscape explicitly gesturing toward both "Africa" and "Cuba" as points of reference? Or how to explain the long history during which an originally "Yoruba" model of containers of the sacred was transposed upon the ceramic forms provided by mass produced "French style" British soup tureens "trickling down" in their function as prestige goods from nineteenth-century grand bourgeois Cuban households to the casas de santo (cult groups of modern regla de ocha) forming at just about the same time? Indeed, 'the possibility that priests could 'choose,' through purchase, the way their Ocha houses and ceremonies looked by selecting from an array of African and European trade goods, as well as from the mundane houseware shelves at the corner bodega, renders quite uninteresting any 
essentialist argument for African origin as a determinant of any given diasporic cultural arrangement." For ultimately, "the place of 'origin' of Cuban Lucumí iconography belongs to the specific historical conjunctures, spaces, and cultural and countercultural imaginations of the "modern' Atlantic world" (Santería Enthroned, p. 273) - a conceptual location, that is, which opens up the possibility of tracking the historical as well as discursive movements of "putatively stable and legitimating origins" as they shift between different temporal and spatial registers (Santería Enthroned, p. 17).

In his discussions of all this - and more! - Brown goes so far beyond the bounds of the theoretical literature on creolization or syncretism available today that one wonders if such conceptual abstractions really can deliver the cargo we have long expected from them. At least in the Cuban case, we now know that this is not so. We need a more differentiated database, a more reflexive methodology, and a sharper focus on what exactly the people whose agency we have become accustomed to subsume under such facile labels intended to achieve, what, historically speaking, such agency amounted to, and how its effects are retrospectively interpreted. Arguably, Brown has advanced this goal in the context of a thoroughly documented case study farther than anyone since the publication of Roger Bastide's Les Religions AfroBrésiliennes in 1960. And I don't think I could do any better than to cite his own conclusions about the state of the field of inquiry I share with him and the other authors of the books reviewed in this essay:

Clearly, the study of Afro-Cuban religions deserves greater dialogue with the full range of Black Atlantic historiography, including studies that contextualize black cultures in relation to national and Atlantic histories ... At the same time, I would not wish to see detailed local ethnographic, closely focused art historical and ethnohistorical inquiry fall by the wayside in such historical investigations. As scholars, we continue to labor under an extremely undeveloped ethnographic and chronological picture of the Afro-Cuban religious systems and their local variations. We have few biographies or close historical studies of Black Atlantic or African Diaspora religious or artistic practitioners ... No intensive ethnohistorical studies exist on the differences in practice among religious houses in Havana and Matanzas, within and among northeastern Brazilian cities in the Candomblé, or between Haitian regions in Vodou, let alone between practices in New York, Miami, and California. A growing number of selfreflexive ethnographic studies of Santería, Vodou, and Candomblé, which revolve around their authors' experiences in relation to these religions, are welcome, but do not always paint the kind of detailed historical picture most needed. (Santería Enthroned, p. 296)

Instead, Brown finds "much to be said for straightforward antiquarian studies of local religion" (p. 296) - and if Santería Enthroned were to represent such antiquarianism, I at least, would heartily concur. Brown's Santería Enthroned has set a standard that will be hard for any of us to match - and 
whether we regard our endeavors as "religious ethnographies" or "ethnographies of religion" may not matter much in this respect. More importantly, however, its ethnographic richness, conceptual power, theoretical subtlety, and sheer brilliance ought to earn it recognition well beyond the field of Afro-Atlantic studies.

\section{REFERENCES}

Appadurai, ArJun, 1986. Introduction: Commodities and the Politics of Value. In Arjun Appadurai (ed.), The Social Life of Things: Commodities in Cultural Perspective. Cambridge: Cambridge University Press, pp. 3-63.

Appiah, Kwame Anthony, 1992. In My Father's House: Africa in the Philosophy of Culture. New York: Oxford University Press.

Barnet, Miguel, 2001. Afro-Cuban Religions. Princeton NJ : Marcus Wiener.

Bascom, William, 1950. The Focus of Cuban Santería. Southwestern Journal of Anthropology 6:64-68.

-, 1951. The Yoruba in Cuba. Nigeria Magazine 37:14-20.

-, 1953. Yoruba Acculturation in Cuba. Mémoires de l'Institut français d'Afrique noire 27:163-67.

BAstide, Roger, 1978. The African Religions of Brazil. Baltimore MD: Johns Hopkins University Press.

Boddy, JANice, 1994. Spirit Possession Revisited: Beyond Instrumentality. Annual Reviews in Anthropology 21:407-34.

BRAga, Julio, 1995. Na gamela do feitiço: Repressão e resistência nos Candomblés da Bahia. Salvador, Brazil: Editora da Universidade Federal da Bahia.

Brandon, George, 1983. The Dead Sell Memories: An Anthropological Study of Santería in New York City. Ph.D. dissertation, Rutgers University, New Jersey.

BRown, DAVID, 1989. Garden in the Machine: Afro-Cuban Sacred Art and Performance in Urban New Jersey and New York. Ph.D. dissertation, Yale University, New Haven CT.

CAPOne, Stefania, 1999. La quête de l'Afrique dans le Candomblé: Pouvoir et tradition au Brésil. Paris: Karthala.

Castellanos, Isabel Mercedes, 1976. The Use of Language in Afro-Cuban Religion. Ph.D. dissertation, Georgetown University, Washington DC.

Comaroff, John \& Jean Comaroff, 1991. Of Revelation and Revolution, Volume 1: Christianity, Colonialism, and Consciousness in South Africa. Chicago: University of Chicago Press. 
-, 1997. Of Revelation and Revolution, Volume 2: The Dialectics of Modernity on a South African Frontier. Chicago: University of Chicago Press.

Das, Veena, 1998. Wittgenstein and Anthropology. Annual Review of Anthropology 27:171-95.

Evans-Pritchard, Edward E., 1956. Nuer Religion. Oxford: Oxford University Press.

Friedman, RoBert Alan, 1982. Making an Abstract World Concrete: Knowledge, Competence, and Structural Dimensions of Performance among Bata Drummers in Santería. Ph.D. dissertation, Indiana University, Bloomington.

Gregory, Steven, 1986. Santería in New York City: A Study in Cultural Resistance. Ph.D. dissertation, New School for Social Research, New York.

HEFner, RoBert W., 1993. World Building and the Rationality of Conversion. In Robert W. Hefner (ed.), Conversion to Christianity: Historical and Anthropological Perspectives in a Great Transformation. Berkeley: University of California Press, pp. 3-43.

-, 1998. Multiple Modernities: Christianity, Islam, and Hinduism in a Globalizing Age. Annual Review of Anthropology 27:84-104.

Herskovits, Melville, 1937. African Gods and Catholic Saints in New World Negro Belief. American Anthropologist 39:635-43.

Horton, Robin, 1984. Judeo-Chrisian Spectacles: Boon or Bane to the Study of African Religions? Cahiers d'Etudes Africaines 96:391-436.

Keane, Webb, 1997. From Fetishism to Sincerity: On Agency, the Speaking Subject, and Their Historicity in the Context of Religious Conversion. Comparative Studies in Society and History 39:674-693.

Kopytoff, IGoR, 1986. The Cultural Biography of Things: Commoditization as Process. In Arjun Appadurai (ed.), The Social Life of Things: Commodities in Cultural Perspective. Cambridge: Cambridge University Press, pp. 64-94.

Landau, Paul, 1999. "Religion" and Christian Conversion in African History: A New Model. Journal of Religious History 23:8-30.

Matory, J. LoRAnd, 1999. The English Professors of Brazil: On the Diasporic Roots of the Yorùbá Nation. Comparative Studies in Society and History 41:72-103.

-, 2001. The "Cult of Nations" and the Ritualization of Their Purity. South Atlantic Quarterly 100:171-214.

MeYer, BIRGit, 1999. Translating the Devil: Religion and Modernity among the Ewe in Ghana. Trenton NJ: Africa World Press.

Meyer, Morris \& Baba Ogunda Bede-Fagbamila, 1991. Ifa and Me: A Divination of Ethnography. Passages 1:6-9.

Mintz, Sidney W. \& Richard Price, 1992. The Birth of African American Culture: An Anthropological Perspective. Boston: Beacon Press. 
Mudimbe, Valentine Y., 1988. The Invention of Africa: Gnosis, Philosophy and the Order of Knowledge. Bloomington: Indiana University Press.

Murphy, Joseph, 1980. Ritual Systems in Cuban Santería. Ph.D. dissertation, Temple University, Philadelphia PA.

Palmié, Stephan, 1991. Das Exil der Götter: Geschichte und Vorstellungswelt einer afrokubanischen Religion. Frankfurt: Peter Lang.

-, 1995. Against Syncretism: Africanizing and Cubanizing Discourses in North American òrìsà-Worship. In Richard Fardon (ed.), Counterworks: Managing the Diversity of Knowledge. London: Routledge, pp. 73-104.

-, 2001. Of Pharisees and Snark Hunters: Afro-Cuban Religion as an Object of Knowledge. Culture and Religion 1:3-19.

PeEL, J.D.Y., 1990. The Pastor and the Babalawo: The Interaction of Religions in Nineteenth-Century Yorubaland. Africa 60:338-69.

-, 2000. Religious Encounter and the Making of the Yoruba. Bloomington: Indiana University Press.

Price, Richard, 1990. Alabi's World. Baltimore MD: Johns Hopkins University Press.

RAFAel, Vicente L., 1988. Contracting Colonialism: Translation and Christian Conversion in Tagalog Society under Early Spanish Rule. Ithaca NY: Cornell University Press.

Sandoval, Mercedes Cros, 1979. Santería as a Mental Health Care System: An Historical Overview. Social Science and Medicine 13:137-51.

ScotT, DAVID, 1991. That Event, This Memory: Notes on the Anthropology of African Diasporas in the New World. Diasporas 1:261-84.

THOMPSOn, Robert FARris, 1983. Flash of the Spirit: African and Afro-American Art and Philosophy. New York: Random House.

Veer, Peter VAn Der (ed.), 1996. Conversion to Modernities: The Globalization of Christianity. New York: Routledge.

Stephan Palmié

Department of Anthropology

University of Chicago

Chicago IL 60637, U.S.A.

<palmie@uchicago.edu> 